\title{
Through a Glass Darkly: Dava Sobel's Galileo's Daughter: A Historical Memoir of Science, Faith and Love
}

\author{
Galileo's daughter: A historical memoir of science, faith and love, by Dava Sobel. \\ New York: Penguin, 2000. Pp xii +420 . S/b $\$ 15.00$.
}

\author{
Kristin P. Jenkins
}

Published online: 20 June 2008

(C) Springer Science + Business Media, LLC 2008
Keywords Nature of science $\cdot$ History and philosophy of science $\cdot$ Science and society

Galileo's Daughter is neither a new book nor about evolution, but it exemplifies the nature of science and illuminates the interaction between science and society. Dava Sobel has written two popular science books: Longitude and Galileo's Daughter. She has a long career as a science writer and in these books, she not only gives clear, basic explanations of the science but also provides a rich social and political context for this scientific work. Reading Galileo 's Daughter, I was struck by the similarities that persist in the relationship between science and society from 1633, when Galileo faced the Inquisition, to 2008, when unpopular scientific theories, such as evolution, face very public political and social rejection.

Ms. Sobel paints a vivid picture of the world in which Galileo lived and worked. The politics and personal decisions of Galileo and other characters are familiar to us today - the hunt for job security, the fiscal demands of supporting a family, enemies seeking revenge, and defense by steadfast friends. For example, Galileo went to great lengths to secure the support of the powerful Medici family, and this paid off for him in the form of a permanent position financed by the Medicis. In return, Galileo named celestial objects for the members of the family, was at their beck and call as a tutor, and was careful to publicize his

K. P. Jenkins $(\bowtie)$

National Evolutionary Synthesis Center,

2024 W. Main St., Suite A200,

Durham, NC 27705, USA

e-mail: kjenkins@nescent.org research in such a manner that it would not offend or alienate them. This stable position was important since Galileo was responsible for the support of his three children, all born out of wedlock in a long-term relationship, and his younger siblings after his father's death. A combination of monetary constraints, his daughter's unmarriageable status, and politics lead Galileo to arrange for his daughters to enter a convent. His older daughter, Virginia, became Sour Maria Celeste when she took her vows, and it is she to whom the title of the book refers. Maria Celeste and Galileo had a special relationship throughout the course of her life, which Ms. Sobel has used in her book to illustrate many of the social and political situations Galileo faced.

The clash between Galileo and the Church echoes the issues we face in today's society. As Ms. Sobel's book clearly indicates, the Catholic Church in Galileo's time was a very powerful political entity and as such engaged in politics and political intrigue just as any other political entity might. The Catholic Church has changed a great deal since then and has moved past many of the issues that caused the refutation of heliocentrism-Copernicus' theory that the Earth and other planets orbit the sun. However, many parallels may be drawn between resistance to scientific concepts then and now. I do not want to suggest that the Catholic Church or any other religious group is inherently anti-science, as I do not believe this to be the case. I simply mean that powerful social and political groups continue to oppose strongly supported, but uncomfortable, scientific ideas.

It is well known that the Inquisition, acting as an agent of the Catholic Church, vilified Galileo for his support of heliocentrism. This book paints an interesting picture of the politics behind this event, and it is enlightening to realize just how important a role politics played in Galileo's confrontation with the church. Heliocentrism had been 
condemned by the Church in 1616. Galileo, a man of strong religious conviction, had no difficulty in accepting what his scientific research told him and maintaining his faith in God. Others were less comfortable with the altered reality of heliocentrism. Moving the Earth, and by extension Man, from the center of all things, and forcing a change in the interpretation of the established spiritual guide made many people profoundly uncomfortable. That being said, many religious leaders had no problem accepting heliocentrism. Although Galileo went to great lengths to avoid conflict with the church, he was caught in a political battle much larger than his scientific claims. The Pope sacrificed Galileo to salvage his own political stature. Galileo's work in support of heliocentrism was not forbidden or prosecuted until the Pope, originally an admirer of Galileo's, needed a way to assert his authority in the face of accusations that he was lax in his defense of the Church. I feel the objections to heliocentrism then are similar to some of the reasons behind the rejection of evolution now - that it removes humans from a central and special place in the universe and requires a major paradigm shift from historical knowledge. This discomfort with paradigm shifts and loss of special status in the universe, as well as changing political tides, is a situation with which we are familiar today with the persistent push against evolutionary theory.

Events of today echo Galileo's work in other ways. Galileo made his science accessible to nonacademics, which is a familiar theme in modern science. His approach to science could be compared to Carl Sagan's. Both chose to use a less academically respected, but more accessible medium for distribution of their science-Sagan through television, and Galileo in Italian instead of the academic language of Latin. Galileo also presented much of his work in plays or dialogues, instead of dense theoretical texts. In fact, Sobel includes a quote from Galileo in which he explains, "I write in the colloquial tongue because I must have everyone read it...I want them to see that just as Nature has given to them, as well as philosophers, eyes with which to see her works, so she has also given them brains capable of penetrating and understanding them."

Galileo's genius is clear in his groundwork for not just one but multiple major paradigm shifts including the study of motion and the heavens. It is also notable and an excellent example of the nature of science that Galileo was flat out wrong in some of his ideas, and in many others his conclusions were limited by the tools of period. His tools are a fascinating study in and of themselves. The telescope, which he did not invent but improved dramatically, lifted astronomical study to a whole new level. Being a practical man, he produced and sold telescopes and an improved compass to supplement his income. The various ingenious methods he developed to measure time and speed in his motion studies are almost as impressive as his major scientific conceptual contributions.

This book provides an excellent demonstration of the National Science Standards for the History and Nature of Science, specifically the concepts of science as a human endeavor, the nature of science, and the history of science. The book is easily accessible for high school or college students and would be a valuable addition to any science or math class for both majors and nonmajors. Both Galileo's successes and failures are presented, which makes him more real and sympathetic. His development of practical tools for his work as well as the limitations of these tools are prime examples of the nature of science. The book illustrates the interaction between society and science, which is particularly compelling because the resistance was so strong to ideas that we now take for granted. 